\title{
Consumers' Knowledge, Attitude, Consumption, and Purchase Intention towards Green Foods in Selected Area in Selangor
}

Annusia Preema Ganesh, Mohaini Mohamed@Naba, Asma' Ali, Siti Nur' Afifah Jaafar

To Link this Article: http://dx.doi.org/10.6007/IJARBSS/v11-i16/11221 DOI:10.6007/IJARBSS/v11-i16/11221

Received: 11 July 2021, Revised: 14 August 2021, Accepted: 28 August 2021

Published Online: 26 September 2021

In-Text Citation: (Ganesh et al., 2021)

To Cite this Article: Ganesh, A. P., Mohamed@Naba, M., Ali, A., \& Jaafar, S. N. A. (2021). Consumers' Knowledge, Attitude, Consumption, and Purchase Intention towards Green Foods in Selected Area in Selangor. International Journal of Academic Research in Business and Social Sciences, 11(16), 102-117.

Copyright: (C) 2021 The Author(s)

Published by Human Resource Management Academic Research Society (www.hrmars.com) This article is published under the Creative Commons Attribution (CC BY 4.0) license. Anyone may reproduce, distribute, translate and create derivative works of this article (for both commercial and non-commercial purposes), subject to full attribution to the original publication and authors. The full terms of this license may be seen at: http://creativecommons.org/licences/by/4.0/legalcode

Special Issue Title: Contemporary Issues in Tourism and Hospitality industry, 2021, Pg. 102 - 117

Full Terms \& Conditions of access and use can be found at http://hrmars.com/index.php/pages/detail/publication-ethics 


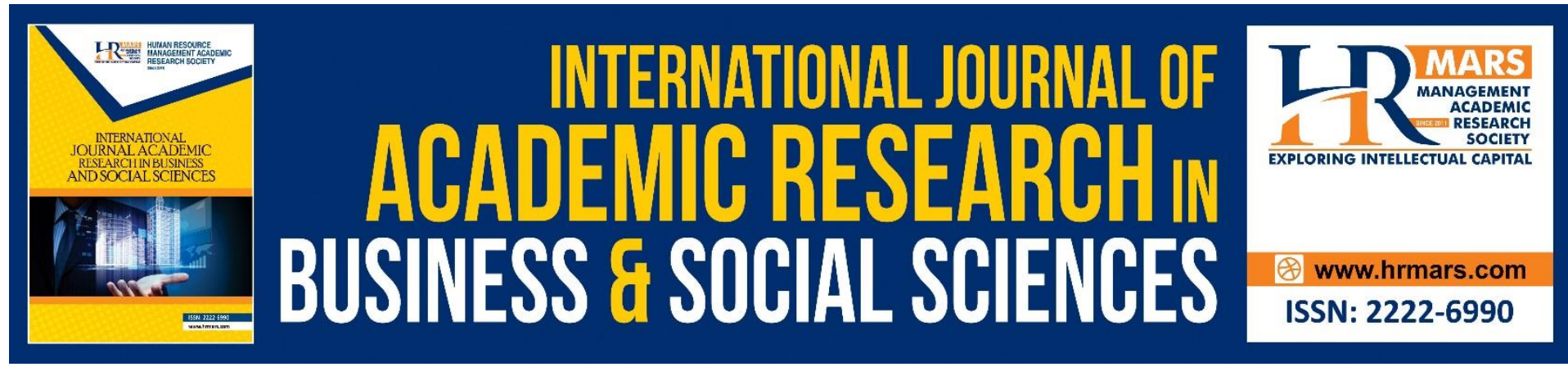

\title{
Consumers' Knowledge, Attitude, Consumption, and Purchase Intention towards Green Foods in Selected Area in Selangor
}

\author{
Annusia Preema Ganesh', Mohaini Mohamed@Naba², Asma' \\ Ali $^{1}$, Siti Nur' Afifah Jaafar ${ }^{1}$ \\ ${ }^{1}$ Universiti Malaysia Terengganu, Malaysia, ${ }^{2}$ Universiti Teknologi Mara Cawangan \\ Terengganu, Malaysia \\ Email: hanee@uitm.edu.my, afifah@umt.edu.my
}

\begin{abstract}
The main objective of this study is to determine the consumers' knowledge, attitude, consumptions, and purchase intention towards green foods in Kajang, Selangor. Additionally, the present study determines the level of knowledge about green foods among the consumers. It also determines the factors that may influence consumers to eat green foods; and examines the association between consumers demographic profiles and their knowledge on green food, attitude, and purchase intention. Consumers who are in the age group of 20 years old and above and shopped green foods in hypermarkets have been chosen as sample for this study. Data are collected by using self-administered questionnaire that is structured into five parts to include the demographic profile, consumers' knowledge on green foods, consumers' attitude towards green foods, consumers' consumption towards green foods, and consumers' purchase intention towards green foods. The collected data was then analysed by using SPSS software. The total number of respondents for this study are $\mathrm{N}=170$. Based on the survey, the frequency of green food consumption by most consumers is at least once within a week. Most of them have good knowledge, positive attitude, and purchase intention towards green foods. Nevertheless, their consumption of green foods is still at average level. Keywords: Green foods, Consumers' Knowledge, Consumers' Purchase Intention
\end{abstract}

\section{Introduction}

Malaysians are getting more educated and concerned about the health and safety of food products. Khan et al (2015) revealed that consumers considered food safety and health issues as prime reasons to purchase green foods. For example, chemical substances that are contained in foods like pesticides, toxins, food additives and more through food processing methods may lead to serious health problems. In the past few years, there has been an incident in April 2008 where the Malaysia government imposed a "self-banned" of its seafood export to the European Union (EU). This is s because the EU found that some Malaysia companielacked health standards and practices set by theby EU (Phuah et al., 2011). Green foods fall under seven categories: grain and oil, fruit, poultry, aquatic and marine products, milk and eggs, vegetables, liquor, and drinks (Cheng, 2014). Green foods comprised two 
dimensions: food safety and sustainability, which have induced high food quality and made it famous worldwide (Yu et al., 2014). The limited amount of chemicals can explain these two dimensions in food quality, pesticides, fertilizers, and additives used in green foods production hence presenting green foods as nutritious, natural, and environmental friendly (Ting et al., 2014).

Today, the environmental and green issues such as climate change, water and air pollutions, and over consumption have caught consumers to consider products that are causing less waste, promote sustainability, and have zero deforestation (Weber et al., 2015). The food products that are selling in the markets used hazardous pesticides and chemical fertilizers in the farms and agriculture lands, which in turn leads them to buy food that contain no nutritious value (Rana \& Paul, 2017). Therefore, an increase of awareness among the consumers has encouraged the manufacturers to respond and emphasize their own environmental commitments to target new customers (Weber et al., 2015). Consumption of food must be mainly depends on safety and quality of food. Safe and high quality foods play an important role in human life to sustain a healthy lifestyle without any disease. Consuming foods that have chemicals and pesticides would worsen a person's health. In the current situation, manufacturers used chemicals in foods to attain longer shelf life. Sadly, having lack of knowledge about green products seems to be the greatest barrier for consumers (Tseng \& Hung, 2013).

Previous studies have used attitude to examine motivation towards purchase intention of green products without factoring in the impacts of environmental consciousness and environmental knowledge (Maichum et al., 2017). However, very few studies have focused on the response of consumers towards green products in the developing countries such as Malaysia (Yadav \& Pathak, 2016). Therefore, this study intends to fill up this gap by focusing on determining the consumers' knowledge, attitude, consumption, and purchase intention towards green foods and determine the level of consumers' knowledge towards green foods. It also aims to determine the factors that may influence the consumers to consume green foods and to determine the association between their demographic profiles and their scores for knowledge, attitude, and purchase intention towards green foods.

\section{Methodology}

There are six largest hypermarkets that repack green products and sell them in their stores in Kajang city in Selangor, Malaysia; and they were selected as the research context for this study. Convenience sampling was used to sample subjects and location, which allowing a large number of respondents to be interviewed in a short period of time since it is quick and easy to access (Hair et al., 2006). Participants were selected based on the inclusion criteria i.e. either men or women aged 20 years old and above; and consumed green food product from the selected hypermarkets. Self-administered survey is the data collection method that was applied in this study hence the respondent reads the survey questions and records his or her own responses without the presence of a trained researcher (Hair et al., 2006).

A face-to-face self-administered and close-ended questionnaire was adopted from Chinna et al. (2012) and developed into two bi-languages namely English and Malay. The questionnaire is divided into five sections, namely Section $A$, about personal information adapting a categorical scale. Section B elucidates questions about consumers' consumption towards 
green food using dichotomous, rating, and categorical scale. For Section C, consumers' knowledge of green foods is asked by using the dichotomous scale. Consumers' attitudes towards green foods are interrogated by using a 5-point Likert in Section D. Finally, Section E elucidates the consumers' purchase intention towards green food that applied 5-point Likert.

All statistical procedures were conducted using Statistical Package for Social Science (SPSS) version 20 software. Initially, Cronbach's alpha was determined for the pilot test to check the reliability of the questionnaire. The closer the Cronbach alpha coefficient to 1 , the greater is the internal consistency of the items in the scale (Cronbach, 1951). Content or face validity was fulfilled when professional reviewer checked the questionnaire while construct validity was achieved through correlation analysis. Using Guilford's rule of thumb (1973), strength of correlation ( $r$ value) is indicated as negligible $(<0.2)$, low $(0.2-0.4)$, moderate $(0.41-0.7)$, and high (0.71-0.9), and very high (>0.9). The Cronbach Alpha's value and the range of $r$, Pearson's correlation coefficient for the Consumers' Attitudes towards Green Food were 0.740 and 0.198-0.669 respectively while for Consumers' Purchase Intention towards Green Food were 0.778 and $0.146-0.726$ respectively.

The data was assumed as normally distributed by applying the central limit theorem (Sirkin, $2005)$ since the sample size is greater than $30(n>30)$ i.e. $n=170$. Therefore, the data were subjected to parametric tests, which included obtaining descriptive statistics and conducting inferential statistical analysis. In this research, the frequencies and percentages for demographic profiles as well as the knowledge about green foods among the respondents have been obtained. Chi-square was used to determine the association between consumers' knowledge about green foods, their attitude towards green foods, their purchase intention towards green foods, and their socio-demographic profiles.

\section{Result and Analysis \\ Respondents}

There are 170 respondents have participated in this research. Table 1 shows a summary of demographic profile of the respondents. 
Table 1: Summary of demographic profile

\begin{tabular}{|c|c|c|}
\hline Demographic Profile & Frequency $(n=170)$ & Percentage (\%) \\
\hline \multicolumn{3}{|l|}{ Gender } \\
\hline \multirow{2}{*}{$\begin{array}{l}\text { Male } \\
\text { Female }\end{array}$} & 49 & 28.8 \\
\hline & 121 & 71.2 \\
\hline \multicolumn{3}{|l|}{ Age } \\
\hline \multirow{5}{*}{$\begin{array}{l}\text { Less than } 20 \text { years old } \\
20-29 \text { years old } \\
30-39 \text { years old } \\
40-49 \text { ears old } \\
\text { More than } 50 \text { years old }\end{array}$} & 3 & 1.7 \\
\hline & 51 & 29.5 \\
\hline & 62 & 35.8 \\
\hline & 42 & 24.3 \\
\hline & 12 & 6.9 \\
\hline \multicolumn{3}{|c|}{ Number of Peoples in Household } \\
\hline \multirow{3}{*}{$\begin{array}{l}1-2 \\
3-4 \\
\text { More than } 5\end{array}$} & 13 & 7.5 \\
\hline & 81 & 46.8 \\
\hline & 76 & 43.9 \\
\hline \multicolumn{3}{|l|}{ Educational Background } \\
\hline \multirow{3}{*}{$\begin{array}{l}\text { Secondary } \\
\text { Post-Secondary } \\
\text { Tertiary }\end{array}$} & 83 & 48.0 \\
\hline & 37 & 21.4 \\
\hline & 50 & 28.9 \\
\hline \multicolumn{3}{|l|}{ Ethnicity } \\
\hline \multirow{4}{*}{$\begin{array}{l}\text { Malay } \\
\text { Chinese } \\
\text { Indian } \\
\text { Others }\end{array}$} & 47 & 27.2 \\
\hline & 48 & 27.7 \\
\hline & 70 & 40.5 \\
\hline & 5 & 2.9 \\
\hline \multicolumn{3}{|l|}{ Employability } \\
\hline \multirow{2}{*}{$\begin{array}{l}\text { Employed } \\
\text { Unemployed }\end{array}$} & 152 & 87.9 \\
\hline & 18 & 10.4 \\
\hline \multicolumn{3}{|l|}{ Monthly Income } \\
\hline \multirow{2}{*}{$\begin{array}{l}\text { Less than RM1500 } \\
\text { RM1500- RM3000 }\end{array}$} & 18 & 10.4 \\
\hline & 39 & 22.5 \\
\hline \multirow{3}{*}{$\begin{array}{l}\text { RM3001-RM6000 } \\
\text { RM6001- RM9000 } \\
\text { More than RM9000 }\end{array}$} & 104 & 60.1 \\
\hline & 8 & 4.6 \\
\hline & 1 & 0.6 \\
\hline
\end{tabular}

Table 1 shows the majority of participants who are in the age group between 30-39 years old (35.8\%). Female respondents are accounted for $71.2 \%$ of the total number of respondents. The highest educational level attained for most respondents is the secondary school education (48\%). The majority of respondents are earning RM 3001- 6000 monthly income (60.1\%) while most respondents are Indians (40.5\%).

\section{Descriptive Statistics of Consumers' Knowledge about Green Foods}

The descriptive data including frequency, percentage, mean, standard deviation of Consumers' Knowledge about Green Foods has been obtained and depicted in Table 2. 
Table 2: Frequency and percentage of the consumers' knowledge answered correctly towards green food consumption in Kajang

\begin{tabular}{|c|c|c|}
\hline Consumers' knowledge towards green foods & $\begin{array}{l}\text { Required } \\
\text { response }\end{array}$ & $\begin{array}{l}\text { Percentage } \\
\text { (\%) }\end{array}$ \\
\hline $\begin{array}{l}\text { Green foods are good for my family member's } \\
\text { health. }\end{array}$ & Yes & 99.4 \\
\hline Green foods are good for health. & Yes & 99.4 \\
\hline $\begin{array}{l}\text { Green foods prevent diseases and increase } \\
\text { immunity. }\end{array}$ & Yes & 99.4 \\
\hline $\begin{array}{l}\text { Green foods have more nutrient than } \\
\text { conventional foods. }\end{array}$ & Yes & 99.4 \\
\hline Green foods are safe foods. & Yes & 99.4 \\
\hline $\begin{array}{l}\text { Green foods are included as foods with no } \\
\text { preservatives, additives and artificial colouring. }\end{array}$ & Yes & 99.4 \\
\hline $\begin{array}{l}\text { Green foods are produced in compliance with } \\
\text { strict quality standard. }\end{array}$ & Yes & 97.6 \\
\hline $\begin{array}{l}\text { Green foods are less polluted and they will not } \\
\text { cause harmful effect on my body. }\end{array}$ & Yes & 94.7 \\
\hline Green foods are expensive. & Yes & 91.8 \\
\hline $\begin{array}{l}\text { Green foods are the foods that are recommended } \\
\text { for safety, quality and nutrition. }\end{array}$ & Yes & 87.6 \\
\hline $\begin{array}{l}\text { Green foods are those foods which use less } \\
\text { chemicals, and have higher vitamin and mineral } \\
\text { content than conventional foods. }\end{array}$ & Yes & 86.5 \\
\hline $\begin{array}{l}\text { Green foods are made of agricultural products } \\
\text { that are planted in pollution-free environment } \\
\text { and processed standardly for strictly control for } \\
\text { content of harmful substance in the food. }\end{array}$ & Yes & 64.7 \\
\hline $\begin{array}{l}\text { Green foods represent a modern life pattern of } \\
\text { eating and drinking. }\end{array}$ & Yes & 55.9 \\
\hline $\begin{array}{l}\text { Green foods' producing process will leave no } \\
\text { contamination to the environment. }\end{array}$ & Yes & 52.4 \\
\hline $\begin{array}{l}\text { Green foods make people think more about } \\
\text { protecting environment. }\end{array}$ & Yes & 47.6 \\
\hline $\begin{array}{l}\text { Developing green foods are contributing to } \\
\text { maintain the environment for the future } \\
\text { generations. }\end{array}$ & Yes & 45.3 \\
\hline $\begin{array}{l}\text { Developing green foods will help to maintain a } \\
\text { better environment for our country. }\end{array}$ & Yes & 44.7 \\
\hline $\begin{array}{l}\text { The ways green foods are produced minimize the } \\
\text { pollution of the world. }\end{array}$ & Yes & 44.1 \\
\hline $\begin{array}{l}\text { Green foods are classified into two grades: the } \\
\text { Double A Grade and the Single A Grade. }\end{array}$ & Yes & 35.3 \\
\hline Green foods are good to taste. & Yes & 33.5 \\
\hline
\end{tabular}

Scale: $1=$ Yes $0=$ No 
Table 2 shows that most consumers know that green foods are good for their family members, good for health, prevent disease and increase immunity, have more nutrients than conventional food, safe food, and foods with no preservative, additives and artificial colouring with $99.4 \%(n=169)$. Although the concept of green is quite new to Malaysia, consumers know that green foods are safe food, good for health, and with no preservatives, additives and artificial colouring (Khan et. al., 2015)Only 33.5\% ( $n=57)$ respondents answered correctly for the knowledge statement of "green foods are good to taste". Comparing to other statements, this statement seems to be the least being answered correctly by the respondents. It is possibly because of the style of green food is prepared. They need to increase their knowledge by finding out on the internet, trusted social media, newspapers on the health section, and many other reliable sources. Green foods provide better taste if they are cook at home rather than buying readily from shop.

For knowledge score, the respondents were required to tick 'Yes', 'No', or 'I don't know'. Each correct answer was given 1 point while 'I don't know' and any invalid answer was given zero (Mohamed et al, 2011). A minimum knowledge score is 0 (0\%) while a maximum of 20 (100\%). These scores were converted to 100 points. Less than or equal to 50 was categorized as poor, 51 to 70 as average, and more than 70 as good level (Gong et al., 2016). The overall knowledge score is $85 \%$, which is considered good knowledge level since more than $70 \%$ indicated good knowledge.

\section{Consumers' Consumption of Green Food}

The percentages of consumers' consumption of green food are shown in Table 3. There are six types of green food consumed by consumers.

Table 3: Percentage of consumers' consumption of green food in Kajang

\begin{tabular}{|l|l|l|l|l|l|}
\hline Statement & Never (\%) & $\begin{array}{l}\text { Almost } \\
\text { Never (\%) }\end{array}$ & $\begin{array}{l}\text { Sometim } \\
\text { es (\%) }\end{array}$ & $\begin{array}{l}\text { Almost Every } \\
\text { time (\%) }\end{array}$ & $\begin{array}{l}\text { Every } \\
\text { time (\%) }\end{array}$ \\
\hline Dairy Product & 1.2 & 31.8 & 60.1 & 4.6 & 0.6 \\
\hline $\begin{array}{l}\text { Fruits } \\
\text { Vegetables }\end{array}$ & 0.0 & 0.0 & 29.5 & 43.9 & 24.9 \\
\hline Meat & 1.2 & 25.4 & 64.7 & 6.4 & 0.6 \\
\hline Bread & 1.2 & 20.8 & 67.6 & 8.1 & 0.6 \\
\hline Packaged Food & 26.6 & 37.6 & 30.6 & 0.6 & 2.9 \\
\hline Others & 94.8 & 1.2 & 1.7 & 0.6 & 0.0 \\
\hline
\end{tabular}

Descriptive test was used.

Scale:5 point Likert scale where 1=Never to $5=$ Everytime

Most of the consumers consumed fruits and vegetables every time (24.9\%). Consumers who are concerned about the naturalness of food seem to be more willing to purchase green food products (Tobler et al., 2011). This is possibly because most of green fruits and vegetables are produced organically without using chemicals. Meanwhile, $94.8 \%$ of the consumers chose 'never' option, which means that other than dairy product, fruits and vegetables, meat, bread, and packaged food. The respondents mentioned other food categories such as nuts, noodles, and seaweed in the questionnaire. 


\section{Descriptive Statistics of Consumers' Attitude, Purchase Intention of Green Food}

Descriptive statistics for Consumers' Attitude, Purchase Intention of Green Food have been obtained and reported in Table 4.

Table 4: Summary of descriptive data

\begin{tabular}{|l|l|}
\hline No & Variables \\
\hline 1. & Consumers' attitude towards Green Food \\
\hline 2. & Safe food \\
\hline 3. & Coalthier than the conventional one \\
\hline 4. & Less polluted \\
\hline 5. & More nutritious than conventional foods \\
\hline
\end{tabular}

Mean \pm Standard Deviation

6. Expensive

$4.13 \pm 0.57$

$4.75 \pm 0.44$

$4.69 \pm 0.47$

$4.68 \pm 0.49$

$4.66 \pm 0.49$

$4.60 \pm 0.49$

7. Free from the risks of harmful additives

8. Safeguard of my health for future

$4.54 \pm 0.61$

9. Related to Green concept in Malaysia

$4.53 \pm 0.51$

10. Quality food

$4.52 \pm 0.50$

11. Not processed using irradiation and chemical food additive

$4.45 \pm 0.52$

12. Prepared in an environmentally friendly way

$4.40 \pm 0.50$

13. Consistent with my life principle

$4.27 \pm 0.54$

14. Powerful antioxidants

$4.21 \pm 0.81$

15. Packaged in an environmentally friendly way

$4.21 \pm 0.50$

16. Well-balanced diet

$4.19 \pm 0.50$

17. Taste better in cooked form rather than raw

$4.18 \pm 0.80$

18. Easily available in the supermarkets

$4.01 \pm 0.58$

19. Harmful for health

$3.44 \pm 0.61$

$3.05 \pm 0.89$

\section{Consumers' purchase intention towards Green Food}

$1.12 \pm 0.57$

20. Consider the quality when I purchase green foods

$4.19 \pm 0.65$

21. Intend to purchase green foods because they are healthy food

$4.82 \pm 0.40$

22. Intend to purchase green foods because they are more concerned

$4.70 \pm 0.50$ about food safety

23. Intend to purchase green foods to avoid illness since unhealthy food may hurt my health

24. Intend to purchase green foods because they are eco-friendly $4.38 \pm 0.57$ product

25. Intend to pay more for green foods for high quality life

$4.47 \pm 0.58$

$4.45 \pm 0.57$

26. Intend to purchase green foods to decrease environmental problems

27. Intend to purchase green foods because of animal welfare issues

28. Have a goal to consume green foods as much as possible

$4.31 \pm 0.59$

$4.28 \pm 0.56$

29. Intend to purchase green foods because they are fresh

$4.25 \pm 0.60$

30. Have adequate knowledge for purchasing green foods

$4.25 \pm 0.64$

31. Have the ability to purchase green foods

$4.24 \pm 0.60$

32. Consider the price when I purchase green foods

$4.24 \pm 0.58$

$4.19 \pm 0.69$ 


\begin{tabular}{|l|l|l|}
\hline 33. & $\begin{array}{l}\text { Intend to purchase green foods because I pay attention to green } \\
\text { foods promotion }\end{array}$ & $4.14 \pm 0.79$ \\
\hline 34. & Consider the taste when I purchase green foods & $3.95 \pm 0.85$ \\
\hline 35. & Consider it is convenient to purchase green foods & $3.15 \pm 0.96$ \\
\hline 36. & Intend to purchase green foods because there are more choices & $3.06 \pm 0.99$ \\
\hline & Factors that Influence Consumers' to Consume Green Food & $3.64 \pm 0.66$ \\
\hline 37. & Safety & $4.65 \pm 0.60$ \\
\hline 38. & Health & $4.56 \pm 0.54$ \\
\hline 39. & Family & $4.21 \pm 0.64$ \\
\hline 40. & Essential & $3.74 \pm 0.69$ \\
\hline 41. & Peer & $3.15 \pm 0.79$ \\
\hline 42. & Curiosity & $3.12 \pm 0.66$ \\
\hline 43. & Tasty & $3.06 \pm 0.64$ \\
\hline 44. & Aesthetic & $2.59 \pm 0.74$ \\
\hline & Overall Factors that Influence Consumers' to Consume Green Food & \\
\hline
\end{tabular}

Descriptive test used 5 point Likert scale where $1=$ strongly disagree to $5=$ strongly agree

Based on the descriptive data in Table 4, consumers generally have positive purchase intention towards green foods $(M=4.23, S . D .=0.63)$ and positive attitude towards green foods ( $M=3.64$, S.D. $=0.66)$. This is possibly because green food has many benefits. Therefore, when consumers have strong intention towards green foods, they are more likely to transfer it into actual purchase (Francis et al., 2012). Table 4 also shows that the consumer perceived that green food is expensive, but that does not prevent them from looking for safe and healthier food. The respondents also agree that the green food is more nutritious than conventional food. Obviously, it is expected that the consumers are more likely to have positive attitude towards green food when they are more concerned about health consciousness and environmental issues (Rahim, 2009). This finding is supported by the Ministry of Health (MOH) campaign entitled 'Go Green Campaign', 'Healthy Lifestyle Campaign' (Hosseinpour et al., 2015), and 'Penang Green Drink' by NGO's. Teng et al. (2011) have also proven that consumers become more concerned about their health and food safety and tend to consume healthy, nutritious, safe, and environmental friendly foods.

\section{Association between Consumers' Knowledge Score towards Green Food and Socio- Demographic Profile}

Table 5 shows the association between consumers' knowledge score towards green food and demographic profile. 
INTERNATIONAL JOURNAL OF ACADEMIC RESEARCH IN BUSINESS AND SOCIAL SCIENCES Vol. 11, No. 16, Contemporary Issues in Tourism and Hospitality industry, 2021, E-ISSN: 2222-6990 @ 2021 HRMARS

Table 5: Association between consumers' knowledge score towards green food and demographic profile

\begin{tabular}{|c|c|c|c|c|}
\hline & \multicolumn{2}{|c|}{$\begin{array}{l}\text { Consumers' Knowledge } \\
\text { Score }\end{array}$} & \multirow[t]{2}{*}{ Total } \\
\hline & & Good & Poor & \\
\hline \multirow[t]{2}{*}{ Gender } & Male & $48(28.2 \%)$ & $1(0.6 \%)$ & 49 (28.8\%) \\
\hline & Female & $101(59.4 \%)$ & $20(11.8 \%)$ & $121(71.2 \%)$ \\
\hline \multicolumn{2}{|l|}{ Total } & $149(87.6 \%)$ & $21(21.4 \%)$ & $170(100 \%)$ \\
\hline \multicolumn{5}{|c|}{$\chi^{2}=6.762, p=0.09, d f=1$} \\
\hline \multirow[t]{5}{*}{ Age } & $<20$ & $3(1.8 \%)$ & $0(0.0 \%)$ & $3(1.8 \%)$ \\
\hline & $20-29$ & $48(28.2 \%)$ & $3(1.8 \%)$ & $51(30.0 \%)$ \\
\hline & $30-39$ & $54(31.8 \%)$ & $8(4.7 \%)$ & $62(36.5 \%)$ \\
\hline & $40-49$ & $34(20.0 \%)$ & $8(4.7 \%)$ & $42(24.7 \%)$ \\
\hline & $\geq 50$ & $10(5.9 \%)$ & $2(1.2 \%)$ & $12(7.1 \%)$ \\
\hline \multicolumn{2}{|l|}{ Total } & $149(87.6 \%)$ & $21(12.4 \%)$ & $170(100.0 \%)$ \\
\hline \multicolumn{5}{|c|}{$\chi^{2}=4.357, p=0.360, d f=4$} \\
\hline \multirow{3}{*}{ 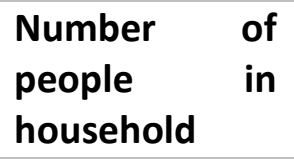 } & $1-2$ & $13(7.6 \%)$ & $0(0.0 \%)$ & $13(7.6 \%)$ \\
\hline & $3-4$ & $69(40.6 \%)$ & $12(7.1 \%)$ & $81(47.6 \%)$ \\
\hline & $\geq 5$ & $67(39.4 \%)$ & $9(5.3 \%)$ & $76(44.7 \%)$ \\
\hline \multicolumn{2}{|l|}{ Total } & $149(87.6 \%)$ & $21(12.4 \%)$ & $170(100.0 \%)$ \\
\hline \multicolumn{5}{|c|}{$\chi^{2}=2.304, p=0.316, d f=2$} \\
\hline \multirow{3}{*}{$\begin{array}{l}\text { Education } \\
\text { Background }\end{array}$} & Secondary & $76(44.7 \%)$ & $7(4.1 \%)$ & $83(48.8 \%)$ \\
\hline & Post-Secondary & $31(81.2 \%)$ & $6(3.5 \%)$ & $37(21.8 \%)$ \\
\hline & Tertiary & $42(24.7 \%)$ & $8(4.7 \%)$ & $50(29.4 \%)$ \\
\hline \multicolumn{2}{|l|}{ Total } & 149 (87.6\%) & $21(12.4 \%)$ & $170(100.0 \%)$ \\
\hline \multicolumn{5}{|c|}{$x^{2}=2.302, p=0.316, d f=2$} \\
\hline \multirow[t]{4}{*}{ Ethnicity } & Malay & $40(23.5 \%)$ & $7(4.1 \%)$ & $47(27.6 \%)$ \\
\hline & Chinese & $42(24.7 \%)$ & $6(3.5 \%)$ & $48(28.2 \%)$ \\
\hline & Indian & $62(36.5 \%)$ & $8(4.7 \%)$ & 70 (41.2\%) \\
\hline & Others & $5(2.9 \%)$ & $0(0.0 \%)$ & $5(2.9 \%)$ \\
\hline \multicolumn{2}{|l|}{ Total } & 149 (87.6\%) & $21(12.4 \%)$ & $170(100.0 \%)$ \\
\hline \multicolumn{5}{|c|}{$\chi^{2}=1.041, p=0.791, d f=3$} \\
\hline \multirow[t]{2}{*}{ Employability } & Employed & $131(77.1 \%)$ & $21(12.4 \%)$ & 152 (89.4\%) \\
\hline & Unemployed & $18(10.6 \%)$ & $0(0.0 \%)$ & $18(10.6 \%)$ \\
\hline \multicolumn{2}{|l|}{ Total } & 149 (87.6\%) & $21(12.4 \%)$ & $170(100.0 \%)$ \\
\hline \multicolumn{5}{|c|}{$x^{2}=2.837, p=0.092, d f=1$} \\
\hline \multirow{4}{*}{$\begin{array}{l}\text { Monthly } \\
\text { Income }\end{array}$} & $<$ RM1500 & $18(10.6 \%)$ & $0(0.0 \%)$ & $18(10.6 \%)$ \\
\hline & RM1500-3000 & 33 (19.4\%) & $6(3.5 \%)$ & 39 (22.9\%) \\
\hline & RM3000-6000 & $92(54.1 \%)$ & $12(7.1 \%)$ & $104(61.2 \%)$ \\
\hline & RM6001-9000 & $5(2.9 \%)$ & $3(1.8 \%)$ & $8(4.7 \%)$ \\
\hline
\end{tabular}


INTERNATIONAL JOURNAL OF ACADEMIC RESEARCH IN BUSINESS AND SOCIAL SCIENCES Vol. 11, No. 16, Contemporary Issues in Tourism and Hospitality industry, 2021, E-ISSN: 222 2-6990 @ 2021 HRMARS

\begin{tabular}{|l|l|l|l|}
\hline \multicolumn{1}{|c|}{$>$ RM9000 } & $1(0.6 \%)$ & $0(0.0 \%)$ & $1(0.6 \%)$ \\
\hline Total & $149(87.6 \%)$ & $21(12.4 \%)$ & $170(100.0 \%)$ \\
\hline$\chi^{2}=\mathbf{7 . 7 4 5}, \mathbf{p}=\mathbf{0 . 1 0 1}, \mathbf{d f}=\mathbf{4}$ & & & \\
\hline Chi-square test was used. & & \\
\hline Scale: $1=$ Yes; $0=$ No & & \\
\hline
\end{tabular}

From Table 5 above, results showed that gender, age, number of people in households, ethnicity, education background, employability, and monthly income have no association ( $p>0.05$ ) with consumers' knowledge of green foods. This is contradicted to Manippa et al. (2017) who found that women responded differently to foods as compared to men. In fact, Davy et al. (2007) reported that women tend to be more invested in food-related issues have better knowledge of food and nutrition, are more prone to go on a diet, and are more likely to perceive themselves as needing to lose weight. Lack of findings on the association between demographic profiles and consumers' knowledge of green foods was found in the past, thus further research of its kind could be carried out in the future.

\section{Association between Consumers' Attitude towards Green Food and Socio-Demographic Profile}

Table 6 shows the association between consumers' attitude towards green food and demographic profile.

Table 6: Association between consumers' attitude towards green food and demographic profile

\begin{tabular}{|c|c|c|c|c|}
\hline & & Consumers' & titude & Total \\
\hline & & High & Average & \\
\hline Gender & Male & $43(25.3 \%)$ & $6(3.5 \%)$ & $49(28.8 \%)$ \\
\hline & Female & $78(45.9 \%)$ & $43(25.3 \%)$ & $121(71.2 \%)$ \\
\hline Total & & $121(71.2 \%)$ & $49(28.8 \%)$ & $170(100 \%)$ \\
\hline$\chi^{2}=9.223, p=0$ & $02, d f=1$ & & & \\
\hline Age & $<20$ & $2(1.2 \%)$ & $1(0.6 \%)$ & $3(1.8 \%)$ \\
\hline & $20-29$ & $43(25.3 \%)$ & $8(4.7 \%)$ & $51(30.0 \%)$ \\
\hline & $30-39$ & $39(22.9 \%)$ & $23(13.5 \%)$ & $62(36.5 \%)$ \\
\hline & $40-49$ & $28(16.5 \%)$ & $14(8.2 \%)$ & $42(24.7 \%)$ \\
\hline & $\geq \mathbf{5 0}$ & $9(5.3 \%)$ & $3(1.8 \%)$ & $12(7.1 \%)$ \\
\hline Total & & $121(71.2 \%)$ & $49(28.8 \%)$ & $170(100.0 \%)$ \\
\hline$\chi^{2}=6.891, p=0$ & $142, d f=4$ & & & \\
\hline Number of & $1-2$ & $10(5.9 \%)$ & $3(1.8 \%)$ & $13(7.6 \%)$ \\
\hline people in & $3-4$ & $52(30.6 \%)$ & $29(17.1 \%)$ & $81(47.6 \%)$ \\
\hline household & $\geq 5$ & $59(34.7 \%)$ & $17(10.0 \%)$ & $76(44.7 \%)$ \\
\hline Total & & $121(71.2 \%)$ & $49(28.8 \%)$ & $170(100.0 \%)$ \\
\hline$x^{2}=3.676, p=0$ & $159, \mathrm{df}=2$ & & & \\
\hline Education & Secondary & 60 (35.3\%) & $23(13.5 \%)$ & $83(48.8 \%)$ \\
\hline Background & Post-Secondary & $21(12.4 \%)$ & $16(9.4 \%)$ & $37(21.8 \%)$ \\
\hline
\end{tabular}


INTERNATIONAL JOURNAL OF ACADEMIC RESEARCH IN BUSINESS AND SOCIAL SCIENCES Vol. 11, No. 16, Contemporary Issues in Tourism and Hospitality industry, 2021, E-ISSN: 222 2-6990 @ 2021 HRMARS

\begin{tabular}{|c|c|c|c|c|}
\hline & Tertiary & $40(23.5 \%)$ & $10(5.9 \%)$ & $50(29.4 \%)$ \\
\hline \multicolumn{2}{|l|}{ Total } & $121(71.2 \%)$ & 49 (28.8\%) & 170 (100.0\%) \\
\hline \multicolumn{5}{|c|}{$\chi^{2}=5.698, p=0.058, d f=2$} \\
\hline \multirow[t]{4}{*}{ Ethnicity } & Malay & $31(18.2 \%)$ & $16(9.4 \%)$ & $47(27.6 \%)$ \\
\hline & Chinese & $36(21.2 \%)$ & $12(7.1 \%)$ & $48(28.2 \%)$ \\
\hline & Indian & $50(29.4 \%)$ & $20(11.8 \%)$ & $70(41.2 \%)$ \\
\hline & Others & $4(2.4 \%)$ & $1(0.6 \%)$ & $5(2.9 \%)$ \\
\hline \multicolumn{2}{|l|}{ Total } & $121(71.2 \%)$ & $49(28.8 \%)$ & $170(100.0 \%)$ \\
\hline \multicolumn{5}{|c|}{$\chi^{2}=1.158, p=0.763, d f=3$} \\
\hline \multirow[t]{2}{*}{ Employability } & Employed & $106(62.4 \%)$ & $46(27.1 \%)$ & $152(89.4 \%)$ \\
\hline & Unemployed & $15(8.8 \%)$ & $3(1.8 \%)$ & $18(10.6 \%)$ \\
\hline \multicolumn{2}{|l|}{ Total } & $121(71.2 \%)$ & $49(28.8 \%)$ & $170(100.0 \%)$ \\
\hline \multicolumn{5}{|c|}{$\chi^{2}=1.450, p=0.228, d f=1$} \\
\hline \multirow{5}{*}{$\begin{array}{l}\text { Monthly } \\
\text { Income }\end{array}$} & $<$ RM1500 & $15(8.8 \%)$ & $3(1.8 \%)$ & $18(10.6 \%)$ \\
\hline & RM1500-3000 & $25(14.7 \%)$ & $14(8.2 \%)$ & $39(22.9 \%)$ \\
\hline & RM3000-6000 & $75(44.1 \%)$ & $29(17.1 \%)$ & $104(61.2 \%)$ \\
\hline & RM6001-9000 & $5(2.9 \%)$ & $3(1.8 \%)$ & $8(4.7 \%)$ \\
\hline & >RM9000 & $1(0.6 \%)$ & $0(0.0 \%)$ & $1(0.6 \%)$ \\
\hline \multicolumn{2}{|l|}{ Total } & $121(71.2 \%)$ & $49(28.8 \%)$ & $170(100.0 \%)$ \\
\hline \multicolumn{5}{|c|}{$\chi^{2}=2.991, p=0.559, d f=4$} \\
\hline \multicolumn{5}{|c|}{ Chi-square test was used. } \\
\hline
\end{tabular}

From Table 6, there is an association $(p<0.05)$ between gender and consumers' attitude. With regards to age groups, number of household, education background, ethnicity, employability and monthly income, there is no association ( $p>0.05$ ) between consumers' attitude and those variables. A researcher found that more educated consumers may be slightly more positive towards the general necessity for green food (Urala \& Lähteenmäki, 2007). Consumers who have higher education level, higher income, and living in the city are likely to aware and have positive attitude towards the green foods (Rezai et al., 2012).

\section{Association between Consumers' Purchase Intention towards Green Food and Socio- Demographic Profile}

Table 7 shows association between consumers' purchase intention towards green food and demographic profile. 
INTERNATIONAL JOURNAL OF ACADEMIC RESEARCH IN BUSINESS AND SOCIAL SCIENCES Vol. 11, No. 16, Contemporary Issues in Tourism and Hospitality industry, 2021, E-ISSN: 2222-6990 @ 2021 HRMARS

Table 7: Association between consumers' purchase intention towards green food and demographic profile

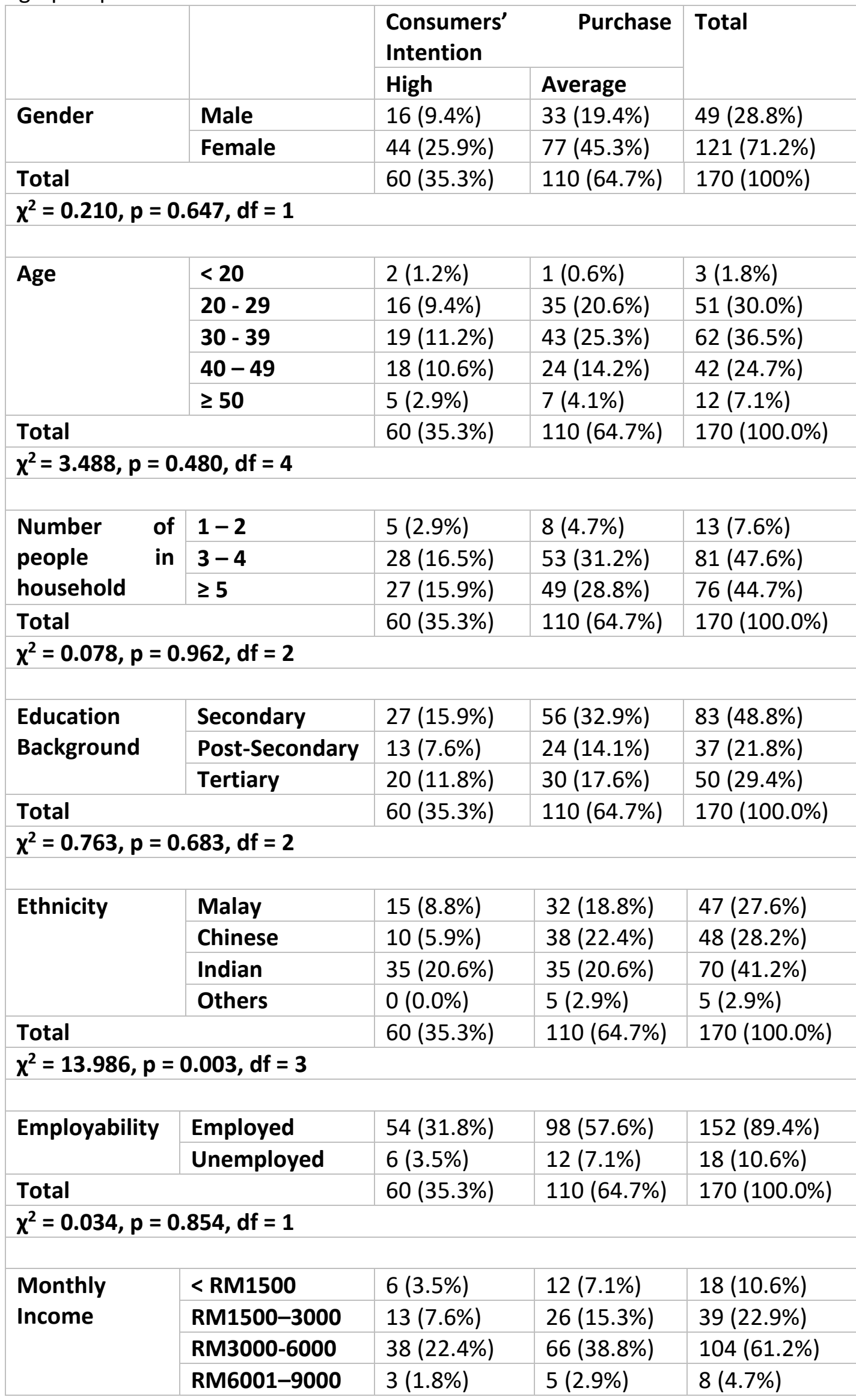


INTERNATIONAL JOURNAL OF ACADEMIC RESEARCH IN BUSINESS AND SOCIAL SCIENCES

Vol. 11, No. 16, Contemporary Issues in Tourism and Hospitality industry, 2021, E-ISSN: 222 2-6990 @ 2021 HRMARS

\begin{tabular}{|c|c|c|c|c|}
\hline & $>$ RM9000 & $0(0.0 \%)$ & $1(0.6 \%)$ & $1(0.6 \%)$ \\
\hline \multicolumn{2}{|l|}{ Total } & $60(35.3 \%)$ & $110(64.7 \%)$ & $170(100.0 \%)$ \\
\hline \multicolumn{5}{|c|}{$\chi^{2}=0.729, p=0.948, d f=4$} \\
\hline \multicolumn{5}{|c|}{ Chi-square test was used. } \\
\hline
\end{tabular}

From Table 7, there is an association $(p<0.05)$ between respondent's ethnicity and consumers' purchase intention. Zakersalehi and Zakersalehi (2012) found that race have significant association with purchase intention of green packaged food. For gender, age groups, educational background, number of household, employability and monthly income, there is no association ( $p>0.05$ ) between consumers' purchase intention and those variable. Male and female are always behave differently and have different consumptions pattern (Solomon 2013). The males being masculine will eat anything to fulfil their hunger (Monge-Rojas, et al., 2015).

The consumer' purchase intention positively affects the probability of a consumer's actual purchase decision on green products (Chen, 2013). In other words, it can be presumed that the willingness of the consumers to purchase a particular product is higher when their purchase intention is high. Therefore, when consumers have strong intention towards the green foods, they are more likely to transfer it into actual purchase (Francis et al., 2012).

\section{Conclusion}

The present study has revealed that most consumers agree that green food is healthy, nutritious, safe, and has no preservatives. Consumers show positive attitude and purchase intention towards green food. There is no association between variables and most of the demographic profiles except for the association between consumers' attitude with gender and consumers' purchase intention towards green food with ethnicity. It is anticipated that these findings are important for the government and non-government agencies in promoting green foods and convey correct information in Malaysia for public by conducting campaigns or related programmes. The finding of this study may not represent consumer behaviour regarding green foods in Malaysia, but it may somehow slightly reflects the current situation of consumers' knowledge, attitude, consumption, and purchase intention towards green foods in selected areas in Selangor. Considerably more work will need to be done in the future to better comprehend the consumer behaviour towards green foods.

\section{Acknowledgement}

The authors would like to thank Faculty of Fisheries and Food Science, Universiti Malaysia Terengganu for the financial support of this research. We thank the anonymous referees for their useful suggestions.

\section{Corresponding Author}

Siti Nur' Afifah Jaafar. Universiti Malaysia Terengganu

Email: afifah@umt.edu.my 


\section{References}

Chen, L. Y. (2013). A Study of Green Purchase Intention Comparing with Collectivistic (Chinese) and Individualistic (American) Consumers in Shanghai, China. Information Management and Business Review, 5(7), 342-346.

Cheng, R. (2014). Strategy Research on Development of Green Food and Security Control in Heilongjiang Province. IERI Procedia, 8, 24-29.

Chinna, K., Karuthan, K., \& Choo, W. Y. (2012). Statistical analysis using SPSS. Pearson Malaysia.

Cronbach, L. J. (1951). Coefficient alpha and the internal structure of tests. Psychometrika. 16, 297-334

Davy, B. M., Van Walleghen, E. L., \& Orr, J. S. (2007). Sex differences in acute energy intake regulation. Appetite, 49(1), 141-147.

Francis, W. V. N., Lee, M. Y., Lin, X. R., \& Low, S. Y. (2012). A study on the youth attitudes toward purchase green products in Malaysia and Singapore. University Tunku Abdul Rahman.

Gong, S., Wang, X., Yang, Y., \& Bai, L. (2016). Knowledge of food safety and handling in households: A survey of food handlers in Mainland China. Food Control, 64, 45-53.

Hair, J. F., Black, W. C., Babin, B. J., Anderson, R. E., \& Tatham, R. L. (2006). Multivariate data analysis (Vol. 6).

Hosseinpour, M., Mohamed, Z., Rezai, G., Shamsudin, M. N., \& AbdLatif, I. (2015). How Go Green Campaign Effects on Malaysian Intention towards Green Behaviour. Journal of Applied Sciences, 15(6), 929.

Khan, M. R. T., Chamhuri, S., \& Farah, H. S. (2015). Green food consumption in Malaysia: a review of consumers' buying motives. International Food Research Journal, 22(1).

Maichum, K., Parichatnon, S., \& Ke-Chung, P. (2017). Factors Affecting on Purchase Intention towards Green Products: A Case Study of Young Consumers inThailand. International Journal of Social Science and Humanity, 7(5), 330.

Manippa, V., Padulo, C., van der Laan, L. N., \& Brancucci, A. (2017). Gender differences in food choice: effects of superior temporal sulcus stimulation. Frontiers in Human Neuroscience, 11, 597.

Mohamed, A. R., Dahl, G. E., \& Hinton, G. (2011). Acoustic modeling using deep belief networks. IEEE Transactions On Audio, Speech, and Language Processing, 20(1), 14-22.

Monge-Rojas, R., Fuster-Baraona, T., Garita, C., Sánchez, M., Smith-Castro, V., ValverdeCerros, O. and Colon-Ramos, U. (2015). The Influence of Gender Stereotypes on Eating Habits Among Costa Rican Adolescents. American Journal of Health Promotion, 29(5), pp.303-310.

Phuah, K., Rezai, G., Mohamed, Z., \& Shamsudin, M. N. (2011). Consumers' Intention to Purchase Green Foods in Malaysia. International Conference on Innovation, Management and Service, 14

Rahim, H. (2009). Consumers' intention and factors affecting green food consumption, Master Dissertation, University Putra Malaysia.

Rana, J., \& Paul, J. (2017). Consumer behavior and purchase intention for organic food: A review and research agenda. Journal of Retailing and Consumer wwServices, 38, 157165.

Rezai, G., Teng, P. K., Mohamed, Z., \& Shamsudin, M. N. (2012). Consumers' awareness and consumption intention towards green foods. African Journal of Business Management 6(12): 4496-4503. 
Sirkin, R. M. (2005). Statistics for the social sciences. Sage Publications.

Solomon, M. R. (2013). Consumer Behaviour: Buying, Having, and Being. 10th ed. Harlow: Pearson Education Limited.

Teng, P. K., Rezai, G., Mohamed, Z., \& Shamsudin, M. N. (2011). Consumers' intention to purchase green foods in Malaysia. In International Conference on innovation, management and service (Vol. 14, pp. 112-118).

Ting, Y. J. Y., Ho, C. T., \& Huang, Q. (2014). Common delivery systems for enhancing in vivo bioavailability and biological efficacy of nutraceuticals. Jounal of Functional Foods. Volume 7, March 2014, 112-128.

Tobler, C., Visschers, V. H., \& Siegrist, M. (2011). Eating green. Consumers' willingness to adopt ecological food consumption behaviors. Appetite, 57(3), 674-682.

Tseng, S. C., \& Hung, S. W. (2013). A framework identifying the gaps between customers' expectations and their perceptions in green products. Journal of Cleaner Production, 59, 174-184.

Urala, N., \& Lähteenmäki, L. (2007). Consumers' changing attitudes towards functional foods. Food Quality and Preference, 18(1), 1-12.

Weber, T., Baier, K., \& Willers, C. (2015). Sustainable (green) food and purchase intention-an analysis of influence factors. International journal on advanced science, engineering and information technology, 5(4), 311-313.

Yadav, R., \& Pathak, G. S. (2016). Young consumers' intention towards buying green products in a developing nation: Extending the theory of planned behavior. Journal of Cleaner Production, 135, 732-739.

Yu, X., Gao, Z., \& Zeng, Y. (2014). Willingness to pay for the "Green Food" in China. Food policy, $45,80-87$.

Zakersalehi, M., \& Zakersalehi, A. (2012, February). Consumers' attitude and purchasing intention toward green packaged foods: A Malaysian perspective. In International Conference on Economics, Business Marketing and Management, Singapore (Vol. 26). 